\title{
Editorial
}

\section{Tularemia in otolaryngology: a forgotten but not gone disease and a possible sign of bio-terrorism}

\author{
Alessandro Rinaldo, M.D., Patrick J. Bradley, M.B.A., F.R.C.S.I., F.R.C.S. (Ed.), F.R.C.S.*,
} Alfio Ferlito, M.D., F.R.C.S. (Ed.), F.R.C.S., F.R.C.S. (Glas.)

\section{Introduction}

Tularemia, also called Ohara's disease, is an acute bacterial infectious disease caused by a pleomorphic, non-mobile, non-capsulated, small Gram negative coccobacillus and zoonotic bacterium, Francisella tularensis. This zoonotic bacteria has reportedly infected a wide range of wild animals (rabbits, hares, squirrels, muskrats, moles, skunks, beavers, deer), some domestic animals (sheep, cattle, cats), birds, some amphibians and many invertebrates (ticks, deer flies, mosquitoes). In the USA and especially the State of Arkansas, the most important reservoir hosts are rabbits, ticks and possibly squirrels. ${ }^{1}$ Humans have occasionally been infected in rural areas, mainly the northern hemisphere. ${ }^{2}$

\section{History}

The first report of $F$. tularensis infection, was described in 1911 by McCoy, ${ }^{3}$ who isolated the bacteria in rodents, who had contracted a plague-like disease in Tulare County, California, USA. McCoy called this organism, Bacterium tularense. Francis $(1921)^{3}$ reported on seven bacteriologically confirmed cases of naturally occurring tularemia and in other cases of laboratory-acquired disease, Parker and Spencer $(1974)^{3}$ discovered the role of ticks in the transmission of tularemia. Ohara $(1925)^{3}$ described the disease in Japan and was able to reproduce the symptoms by voluntary inoculation of his wife. In recognition of Francis's life-long contributions to the study of tularemia, the American Medical Association nominated him for the Nobel Prize in Medicine. In 1959, the name of the organism's genus was changed to Francisella. ${ }^{3}$ The peak observed incidence of tularemia occurred in 1939, and most present-day clinicians have never seen a case of this disease. 4

\section{Transmission and epidemiology}

Three main biovars of $F$. tularensis are responsible for this zoonosis: the highly virulent biovar A (biovar tularensis), which is found mostly in Northern America and exceptionally in Europe; biovar B (palaearctica), which is not as virulent as biovar A and which is present in Europe, Asia and rarely, in Northern America; and biovar novicida, which has been considered a third biovar of $F$. tularensis. ${ }^{5,6}$ It can be transmitted to humans by insect vectors, such as ticks or deer flies, handling or ingestion of infected animal tissues, inhalation of infectious aerosol or the consumption of contaminated drinking water (the bacteria have been isolated from environmental sources such as the mud and water from streams and wells). Tularemia is an occupational hazard for humans who work as rabbit hunters, butchers, cooks, processors of frozen wild rabbit meat or pelts, agricultural workers, campers, sheep herders and shearers, mink ranchers, muskrat farmers and occasionally laboratory technicians. Tularemia has also been reported in urban areas, as well as rural areas. Evisceration of animals infected with tularemia provides ample opportunity for contamination of the workers' skin. 'Transmission of tularemia between humans occurs, but only occasionally, 8,9 and has been reported occurring in the same family. ${ }^{10}$ Approximately 12 cases occur annually in the USA and approximately 25 per cent of cases occur in children six years of age or younger. ${ }^{11}$ During the period 1975-1990, 105 cases of tularemia have been reported to the nationwide notification system for infectious diseases in Norway. ${ }^{12}$

\section{Infective agent}

Recent bio-terror attacks and other world events have focused the medical community's attention on infective agents that might be used in biological warfare. One of these potential biological weapons is F. tularensis. ${ }^{13}$ For potential bio-terrorism-related conditions that are endemic and have low incidence, the use of nontraditional surveillance methods and complementary data sources may enhance our ability to rapidly detect changes in disease incidence. ${ }^{14}$ Between 11 and 45 per cent of patients with 
tularemia have symptoms or signs localized to the head and neck region, ${ }^{5,15,16}$ but only a few reports have been published in journals of our speciality. $1,3,5,7,10,13,16,17$

\section{Histopathology}

The lesion consists of a granulomatous reaction that in some cases may have a frankly tuberculoid appearance, in particular in the more chronic lesions, but the necrosis is more liquefactive than caseous. The widespread necrosis with polymorphs, lymphocytes and multinucleated giant cells is surrounded by radially arranged epithelioid cells and fibrosis.

\section{Clinical manifestations}

The clinical manifestation of tularemia may vary from asymptomatic illness to fulminant toxaemia with septic shock, and presentation is dependant on the organism and the route of transmission. Symptoms may include fever, tonsillitis, painful cervical adenitis, ulcers, chill, fatigue and headache. The manifestations of tularemia are traditionally classified into different clinical types depending on the route of transmission: ulceroglandular, glandular, oropharyngeal, oculoglandular, typhoidal and pneumonic tularemia. Table I tabulates the six forms of this disease as currently identified and their estimated relevant incidences. ${ }^{18}$ Thus the most frequent clinical presentations are the ulceroglandular, glandular and oculoglandular forms, which occur after the individual has handled affected animals. Pharyngeal infections after ingestion of inadequately cooked meat or contaminated water have been reported. Apart from oropharyngeal (and oculoglandular) tularemia, the main symptoms and signs of both the ulceroglandular and the glandular form may be seen in the head and neck region. F. tularensis can also cause lung infections ${ }^{19}$ after inhalation of infectious aerosols or systemic illness, such as typhoidal tularemia. When there is pulmonary involvement, it is accompanied by pleural disease. There have been reported cases of bacteraemia caused by $F$. tularensis world-wide, mainly in the USA and more frequently in Northern Europe Norway and Sweden. These cases have been associated with underlying immunodeficiencies in some cases, but other cases are associated with underlying penumonia.

TABLE I

THE SIX FORMS OF TULAREMIA AND THEIR RELATIVE INCIDENCE*

\begin{tabular}{lc}
\hline Clinical syndrome & Relative incidence \\
\hline Ulceroglandular tularemia & $80 \%$ \\
Glandular tularemia & $15 \%$ \\
Oropharyngeal tularemia & $<5 \%$ \\
Oculoglandular tularemia & $1 \%$ \\
Typhoidal tularemia & $<1 \%$ \\
Pneumonic tularemia & $<1 \%$ \\
\hline
\end{tabular}

*From Levy and Chiang ${ }^{18}$

\section{Otolaryngological presentations}

In otolaryngological practice, tularemia may manifest with a variety of clinical features which, in many instances, are difficult to recognize as they are nonspecific, such as fever and cervical lymphadenopathy. The oropharyngeal form of tularemia should be considered in the differential diagnosis of cases with tonsillo-pharyngitis with accompanying extensive necrotic cervical lymphadenitis, ${ }^{6,20}$ in particular, tularemia should be considered in patients who do not respond to penicillin treatment, even in areas where it is not endemic. ${ }^{17}$ The differential diagnosis for such clinical symptoms includes: cat scratch disease, Lyme disease, tuberculosis, diphtheria, infectious mononucleosis, fungal and rickettsial infections, lymphoma and leukaemia. ${ }^{1,21,22}$ Cervical lymph nodes may be the seat of the typical granulomatous reaction when the site of the infection is the face.

\section{Radiological imaging}

The radiological imaging features of tularemia are not specific. ${ }^{17}$ Enlarged lymph nodes with central necrosis may be well demonstrated by magnetic resonance imaging (MRI), associated with hypertrophy of the tonsils, adenoids and lymph nodes in children. $^{23}$

\section{Confirmatory diagnosis}

It is difficult to make a final diagnosis of tularemia and it is frequently delayed because of its relative rarity and the inconsistency of its characteristics. ${ }^{13} \mathrm{~A}$ history of having handled rabbits should suggest the possible diagnosis in the first instance. The confirmatory diagnosis is made by finding the organisms in material from infected tissues and is supported by a rise in haemagluttinin titres. A result is positive when there is a single titre of $1: 160$ or greater. ${ }^{13}$ Patients with tularemia usually develop a diagnostic titre two to four weeks after the onset of symptoms. The white blood count is usually normal. If a tissue biopsy is taken from a tularemic lymph node or abscess, the histopathologic findings may be proven by the use of fluorescence-labelled antibodies. Newer techniques, such as polymerase chain reaction, enzyme-linked immunoassay, and pulsed-field gel electrophoresis are reported to be quicker and more sensitive. ${ }^{24,25}$

\section{Treatment and prevention}

Several antibiotics such as streptomycin, gentamicin, or chloramphenicol have been shown to be effective in the treatment of tularemia. Intramuscular streptomycin $(10 \mathrm{mg} / \mathrm{Kg}$ twice daily for 14 days $)$ has been considered the management of choice. F. tularensis is resistant to $\beta$-lactam antibiotics, including ceftriaxone. ${ }^{26}$ Surgical drainage of any fluctuant abscess is also indicated. ${ }^{13}$ Limaye and Hooper ${ }^{27}$ have found that ciprofloxacin was effective in treating tularemia in immunosuppressed patients. 
A live attenuated vaccine strain (LVS) has been used in humans as an investigational new drug and does appear to induce a protective response. ${ }^{28}$

\section{Conclusion}

Considering that many cases of tularemia are characterized by head and neck symptoms, otolaryngologists should be familiar with the diagnosis and management of this disease.

\section{References}

1 Wills PI, Gedosh EA, Nichols DR. Head and neck manifestations of tularemia. Laryngoscope 1982;92:770-3

2 Pikula J, Treml F, Beklova M, Holesovska Z, Pikulova J. Ecological conditions of natural foci of tularaemia in the Czech Republic. Eur J Epidemiol 2003;18:1091-5

3 Collison PJ, Adams B. Glandular tularemia in a Native American child. Ear Nose Throat J 2003;82:851-4

4 Jensen WA, Kirsch CM. Tularemia. Semin Respir Infect 2003;18:146-58

5 Luotonen J, Syrjälä H, Jokinen K, Sutinen S, Salminen A. Tularemia in otolaryngologic practice. An analysis of 127 cases. Arch Otolaryngol Head Neck Surg 1986;112:77-80

6 Haristoy X, Lozniewski A, Tram C, Simeon D, Bevanger L, Lion C. Francisella tularensis bacteremia. J Clin Microbiol 2003;41:2774-6

7 Richtsmeier WJ, Johns ME. Bacterial causes of granulomatous diseases. Otolaryngol Clin North Am 1982;15:473-92

8 Helvaci S, Gedikoglu S, Akalin H, Oral HB. Tularemia in Bursa, Turkey: 205 cases in ten years. Eur J Epidemiol 2000;16:271-6

9 Perez-Castrillon JL, Bachiller-Luque P, Martin-Luquero M, Mean-Martin FJ, Herreros V. Tularemia epidemic in northwestern Spain: clinical description and therapeutic response. Clin Infect Dis 2001;33:573-6

10 Benlyazid A, Lescanne E, Borderon JC, Ployet MJ. [Cervicofacial manifestations of tularemia. Apropos of a familial case]. Ann Otolaryngol Chir Cervicofac 1997;114:80-3 (in French)

11 From the Centers for Disease Control and Prevention. Plague-United States, 1992. J Am Med Assoc 1992;268:3055

12 Scheel O, Reiersen R, Hoel T. Treatment of tularemia with ciprofloxacin. Eur J Clin Microbiol Infect Dis 1992;11:447-8

13 Stupak HD, Scheuller MC, Schindler DN, Ellison DE. Tularemia of the head and neck: a possible sign of bioterrorism. Ear Nose Throat J 2003;82:263-5

14 Chang MH, Glynn MK, Groseclose SL. Endemic, notifiable bioterrorism-related diseases, United States, 1992-1999. Emerg Infect Dis 2003;9:556-74
15 Evans ME, Gregory DW, Schaffner W, McGree ZA. Tularemia: a 30-year experience with 88 cases. Medicine (Baltimore) 1985;64:251-69

16 Nordahl SH, Hoel T, Scheel O, Olofsson J. Tularemia: a differential diagnosis in oto-rhino-laryngology. J Laryngol Otol 1993;107:127-9

17 Arikan OK, Koç C, Bozdoğan O. Tularemia presenting as tonsillo-pharyngitis and cervical lymphadenitis: a case report and review of the literature. Eur Arch Otorhinolaryngol 2003;260:298-300

18 Levy PD, Chiang WK. Update on emerging infections: news from the Centers for Disease Control and Prevention. Ann Emerg Med 2002;40:181-4

19 Syrjälä Hk, Sutinen S, Jokinen K, Nieminen P, Tuuponen $\mathrm{T}$, Salminen A. Bronchial changes in airborne tularemia. $J$ Laryngol Otol 1986;100:1169-76

20 Umlas SL, Jaramillo D. Massive adenopathy in oropharyngeal tularemia; CT demonstrations. Pediatr Radiol 1990;20:483-4

21 Lennert K. [Classification and morphology of non-Hodgkin's lymphomas]. Hamatol Bluttransfus 1976;18:145-50 (in German)

22 Grunow R, Splettstosser W, Hirsch FW, Kleemann D, Finke EJ. [Differential diagnosis of tularemia]. Dtsch Med Wochenschr 2001;126:408-13 (in German)

23 Robson CD. Imaging of granulomatous lesions of the neck in children. Radiol Clin North Am 2000;38:969-77

24 Labayru C, Palop A, Lopez-Urrutia L, Avellaneda C, Mazon MA, Alberte A, et al. [Francisella tularensis: update on microbiological diagnosis after an epidemic outbreak]. Enferm Infecc Microbiol Clin 1999;17:458-62 (in Spanish)

25 Johansson A, Berglund L, Eriksson U, Goransson I, Wollin R, Forsman M, et al. Comparative analysis of PCR versus culture for diagnosis of ulceroglandular tularemia. $J$ Clin Microbiol 2000;38:22-6

26 Cross JT, Jacobs RF. Tularemia: treatment failures with outpatient use of ceftriaxone. Clin Infect Dis 1993;17:976-80

27 Limaye AP, Hooper CJ. Treatment of tularemia with fluoroquinolones: two cases and review. Clin Infect Dis 1999;29:922-4

28 Titball R, Oyston P. A vaccine for tularaemia. Expert Opin Biol Ther 2003;3:645-53

Address for correspondence:

A. Perlito, M.D., F.R.C.S. (Ed.), F.R.C.S., F.R.C.S. (Glasg.)

Director of the Department of Surgical Sciences,

Professor and Chairman of the ENT Clinic,

University of Udine, Policlinico Universitario*,

I-33100 Udine, Italy.

Fax: 390432559339

E-mail: a.ferlito@uniud.it 